\title{
Congenital Vitamin K-Dependent Clotting Factors Deficiency Type 1: A Rare Bleeding Disorder
}

\author{
Sura Ahmed Al-Doory Mahmoud Ahmed Radaideh Shafeeka Mohamed Saleh \\ Mohammed Ali Al Sabbah
}

Pediatrics Department, Latifa Women's and Children's Hospital, Dubai Health Authority, Dubai, UAE

\section{Keywords}

Vitamin $\mathrm{K} \cdot \mathrm{\gamma}$-Glutamyl carboxylase $\cdot$ Epoxide reductase complex $\cdot$ Whole-exome sequencing $\cdot$ Hemorrhage, clotting factors

\begin{abstract}
Combined deficiency of vitamin K-dependent clotting factors is usually an acquired clinical problem, often resulting from liver disease, malabsorption or warfarin overdose. However, an inherited form of the disease is very rare. Here we report a 4-month-old girl who presented with a 2-week history of multiple bruises and a 1-day history of right thigh swelling after receiving her 4 th month vaccine. Laboratory investigations showed anemia ( $\mathrm{Hb} 6.0 \mathrm{~g} / \mathrm{dL}$ ) with extremely prolonged PT and APTT. Factor assay revealed deficiency of vitamin K-dependent clotting factors II, VII, IX, X as well as protein $C$ and protein $S$. Whole-exome sequencing detected a novel homozygous mutation (c.44-5T>A p.(?)) in the $\mathrm{Y}$-glutamyl carboxylase (GGCX) gene responsible for the autosomal recessive combined vitamin $\mathrm{K}$-dependent clotting factors deficiency type 1.

(c) 2020 The Author(s) Published by S. Karger AG, Basel
\end{abstract}

\begin{tabular}{ll}
\hline KARGER & (c) 2020 The Author(s) \\
& Published by S. Karger AG, Basel \\
karger@karger.com & This article is licensed under the Creative Commons Attribution- \\
www.karger.com/dmj & NonCommercial-NoDerivatives 4.0 International License (CC BY- \\
NC-ND) (http://www.karger.com/Services/OpenAccessLicense). \\
Usage and distribution for commercial purposes as well as any dis- \\
tribution of modified material requires written permission.
\end{tabular}

\section{Introduction}

Hereditary combined vitamin K-dependent clotting factors deficiency (VKCFD) is a rare congenital bleeding disorder resulting in variably decreased levels of coagulation factors II, VII, IX and X as well as natural anticoagulants protein $\mathrm{C}$, protein $\mathrm{S}$ and protein $\mathrm{Z}$ [1]. Bleeding manifestation ranges from mild to severe with onset in the neonatal period in severe cases [2]. Easy bruising is a common presentation; however, bleeding symptoms could be life-threatening. It can occur spontaneously, with minor trauma or in a surgical setting. Bleeding from the umbilical cord has been reported $[3,4]$, while hemarthrosis is rarely described [4]. Mucocutaneous bleeding, such as gastrointestinal bleeding, may also appear after antibiotic therapy, because of the decreased vitamin $\mathrm{K}$ production by gut bacteria. VKCFD can sometimes cause fatal intracranial hemorrhage in the first weeks of life, which is similar to the hemorrhagic disease of newborns that results from acquired vitamin $\mathrm{K}$ deficiency $[3,5,6]$.

A range of nonhomeostatic symptoms is often present, including developmental and skeletal anomalies resembling those seen in warfarin embryopathy [2]. It includes stippling of the long bone epiphyses, shortness of fingers' distal phalanges and nasal hypoplasia [5, 7]. Osteoporosis

Sura Ahmed Al Doory

Pediatrics Department, Latifa Women's and Children's Hospital Oud Metha street

PO Box 9115, Dubai (UAE)

saaldoory@dha.gov.ae 
Table 1. Comparison between investigations done in hospital versus investigations done in primary health center (PHC)

Investigations done in hospital

Investigations done in PHC

$\begin{array}{ll}\text { FBC } & \\ \text { WBC } & 32.8\left(6.0-18.0 \times 10^{3} / \mu \mathrm{L}\right) \\ \text { RBC } & 3.08\left(4.10-5.30 \times 10^{3} / \mu \mathrm{L}\right) \\ \mathrm{Hb} & 6.0(11.1-14.1 \mathrm{~g} / \mathrm{dL}) \\ \mathrm{HCT} & 17.8(30.0-40 \%) \\ \mathrm{MCV} & 19.5(68.0-84.0 \mathrm{fL}) \\ \mathrm{MCH} & 24.8(11.5-14.0 \%) \\ \text { RDW } & 370\left(200-550 \times 10^{3} / \mu \mathrm{L}\right) \\ \text { Platelets } & >\text { maximum }(11-14 \mathrm{~s}) \\ \text { PT } & >\text { maximum }(28-41 \mathrm{~s}) \\ \text { APTT } & \end{array}$

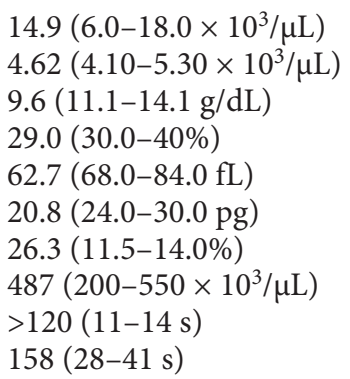

without the classical serum circulating markers of bone rearrangement and pseudoxanthoma elasticum-like disorders have been reported [7-9].

VKCFD is an autosomal recessive disorder caused by mutations in the genes of either $\gamma$-glutamyl carboxylase or vitamin K2,3-epoxide reductase complex [2, 10]. These two proteins are necessary for $\gamma$-carboxylation, a post-synthetic modification that allows coagulation proteins to display their proper function [2]. The developmental and skeletal anomalies seen in VKCFD are the result of defective $\gamma$-carboxylation of a number of nonhemostatic proteins [2]. It is important to differentiate this condition from other conditions, both congenital or acquired and genotype analysis is needed to confirm the diagnosis. Vitamin $\mathrm{K}$ administration is the mainstay of therapy in VKCFD; however, during surgery or severe bleeding episodes, fresh frozen plasma (FFP) supplementation will be needed. In addition, prothrombin complex concentrates and combination therapy with recombinant activated FVII and vitamin $\mathrm{K}$ supplementation may constitute alternative treatment options [2]. With early diagnosis and early initiation of therapy, VKCFD has a good prognosis with a minimal impact on the quality of life of the affected patients. Nonetheless, permanent disabling consequences could occur in severely affected patients who have been diagnosed after critical events such as intracranial hemorrhage [2].

\section{Case Report}

A previously healthy 4-month-old Syrian girl was referred to our hospital from the primary health center with a 2-week history of easy bruising over the abdominal wall and upper limbs and a 1 -day history of right thigh swelling after receiving the 4th month vaccine. She was born at 41 weeks of gestation by normal vaginal delivery; birth weight: $3.295 \mathrm{~kg}$, length: $48 \mathrm{~cm}$ and head circumference: $35 \mathrm{~cm}$. Antenatal and postnatal history were unremarkable. The baby received a vitamin $\mathrm{K}$ injection after birth and her newborn screening was normal.

She was on exclusive breastfeeding; her growth and development were normal for her age. She is the only child to 1st-cousin parents. There was no family history of a similar bleeding disorder, liver disease or other inherited disorders.

On examination, the following was found: temperature $38.2^{\circ} \mathrm{C}$, HR $168 / \mathrm{min}$, RR 42/min, BP 98/54 $\mathrm{mm} \mathrm{Hg}$ and $\mathrm{SpO}_{2} 95 \%$ in room air. Her weight was $7.7 \mathrm{~kg}$ (92nd centile on the WHO growth charts) and her length was $63 \mathrm{~cm}$ (24.8th centile on the WHO growth charts). She was crying, looked uncomfortable, pale but well perfused. She has subtle craniofacial dysmorphic features including bilateral temporal baldness, a prominent forehead, a short depressed nasal bridge, small nares, a short philtrum and micrognathia. Systemic examination was unremarkable apart from a tender, warm ill-defined swelling of the anterior aspect of the right thigh associated with limited right knee extension. In addition, she had multiple ecchymosis over the trunk and upper extremities.

Initial investigations in the primary health center showed a disturbed coagulation profile with $\mathrm{Hb}$ of $9.6 \mathrm{~g} / \mathrm{dL}$. In less than $24 \mathrm{~h}$, repeated lab investigations in our hospital revealed a drop of $\mathrm{Hb}$ to $6.0 \mathrm{~g} / \mathrm{dL}$ and worsening of her coagulation profile (Table 1).

Ultrasound of the right thigh showed evidence of diffuse edema overlying the subcutaneous soft tissue, otherwise no collection was seen. She received FFP, packed RBC and intravenous vitamin K. She was started on intravenous antibiotics in view of the suspicion of cellulitis of the right thigh.

Repeated lab investigations after $12 \mathrm{~h}$ showed improvement of the coagulation profile (PT $16.1 \mathrm{~s}$, APTT $51.7 \mathrm{~s}$ ) and Hb increased to $9.1 \mathrm{~g} / \mathrm{dL}$. From day 2 onwards, she became afebrile, thigh swelling was improving, and ecchymosis started to fade.

Factor assay showed: factor II: 3\% (70-120\%), factor VII: $4 \%$ (70-130\%), factor IX: 5\% (70-120\%), factor X: $2 \%$ (70-150\%), factor V: $92 \%$ (70-120\%), factor VIII 191\% (60-200\%) and von Willebrand factor: $101 \%(50-200 \%)$. Both protein S and protein C were low as well, $7 \%(60-160 \%)$ and 3\% (70-140\%), respectively. 
Table 2. Whole-exome sequencing

\begin{tabular}{|c|c|c|c|c|c|c|c|c|}
\hline \multirow{2}{*}{$\begin{array}{l}\text { Gene } \\
\text { (isoform) }\end{array}$} & \multirow{2}{*}{$\begin{array}{l}\text { OMIM-P (mode of } \\
\text { inheritance) }\end{array}$} & \multirow[t]{2}{*}{ Variant } & \multicolumn{3}{|c|}{ Zygosity } & \multirow{2}{*}{$\begin{array}{l}\text { MAF } \\
\text { gnomAD, \% }\end{array}$} & \multirow{2}{*}{$\begin{array}{l}\text { Literature } \\
\text { [PMID] }\end{array}$} & \multirow[t]{2}{*}{ Classification } \\
\hline & & & index & mother & father & & & \\
\hline $\begin{array}{l}\text { GGCX } \\
\left(\mathrm{NM} \_000821.5\right)\end{array}$ & $\begin{array}{l}277450(\mathrm{AR}) \\
610842(\mathrm{AR})\end{array}$ & $\begin{array}{l}\text { c. } 44-5 \mathrm{~T}>\mathrm{A} \\
\text { p.(?) } \\
\text { chr2:85788113 }\end{array}$ & hom. & het. & het. & 0 & - & $\begin{array}{l}\text { Variant of uncertain } \\
\text { significance }\end{array}$ \\
\hline $\begin{array}{l}\text { VWF } \\
\text { (NM_000552.3) }\end{array}$ & $613554(\mathrm{AR}, \mathrm{AD})$ & $\begin{array}{l}\text { c. } 5191 \mathrm{~T}>\mathrm{A} \\
\text { p.(Ser1731Thr) } \\
\text { chr12:6125802 }\end{array}$ & het. & het. & het. & 0.15 & 11583318 & $\begin{array}{l}\text { Variant of uncertain } \\
\text { significance }\end{array}$ \\
\hline $\begin{array}{l}\text { HBB } \\
(\mathrm{NM} \text { _000518.4) }\end{array}$ & $\begin{array}{l}603903(\mathrm{AR}) \\
613985(\mathrm{AR})\end{array}$ & $\begin{array}{l}\text { c. } 19 \mathrm{G}>\mathrm{A} \\
\text { p.(Glu7Lys) } \\
\text { chr11:5248233 }\end{array}$ & hom. & het. & het. & 0.12 & 8294201 & Pathogenic \\
\hline
\end{tabular}

To rule out secondary causes of vitamin K-dependent clotting factors deficiency, liver function test, stool analysis, pancreatic lipase and sweat chloride tests were done; all were normal.

On day 7, PT and APTT were again prolonged (PT $51.0 \mathrm{~s}$, APTT 65.6 s), a 2nd dose of vitamin $\mathrm{K}$ was given. Three days later, repeated PT and APTT were still slightly prolonged (PT $32.5 \mathrm{~s}$, APTT $48.4 \mathrm{~s}$ ), but she remained stable; therefore, she was discharged on oral vitamin K 2 mg every other day.

She has regularly been followed in our pediatric hematology clinic, hereditary combined vitamin K-dependent clotting factors deficiency was considered as a likely underlying cause. Thus, she was investigated further by whole-exome sequencing, which detected a novel homozygous mutation (c.44-5T $>\mathrm{A}$ p.(?)) in the GGCX gene responsible for an autosomal recessive combined vitamin K-dependent clotting factors deficiency type 1. Both parents were heterozygous for the same mutation (Table 2).

Interestingly, whole-exome sequencing detected a heterozygous mutation (c.5191T $>$ A, p.(Ser1731Thr)) in the von Willebrand factor (VWF) gene responsible for autosomal dominant von Willebrand disease type 1 . Both parents were heterozygous for the same.

Furthermore, a homozygous pathogenic variant (c.19G $>$ A p.(Glu7Lys)) in the HBB gene responsible for hemoglobin C disease was also detected. Both parents were heterozygous. $\mathrm{Her} \mathrm{Hb}$ electrophoresis showed $\mathrm{Hb} \mathrm{F} 7.5 \%, \mathrm{Hb}$ A2 3.3\%, and $\mathrm{Hb}$ C 88.7\%, consistent with homozygous $\mathrm{Hb} \mathrm{C}$ disease.

Moreover, skeletal survey was done which was normal except for the absent nasal bone, which could be attributed to the nonhemostatic manifestations associated with VKCFD (Fig. 1).

On follow-up, she has been doing well, with no bleeding manifestation and an almost normal coagulation profile thereafter. Her last clinic visit was at the age of 20 months; the dose of oral vitamin $\mathrm{K}$ has been adjusted to $4 \mathrm{mg}$ every other day.

\section{Discussion/Conclusion}

Combined deficiency of vitamin K-dependent clotting factors is usually an acquired clinical problem. A rare inherited form of defective $\gamma$-carboxylation resulting in

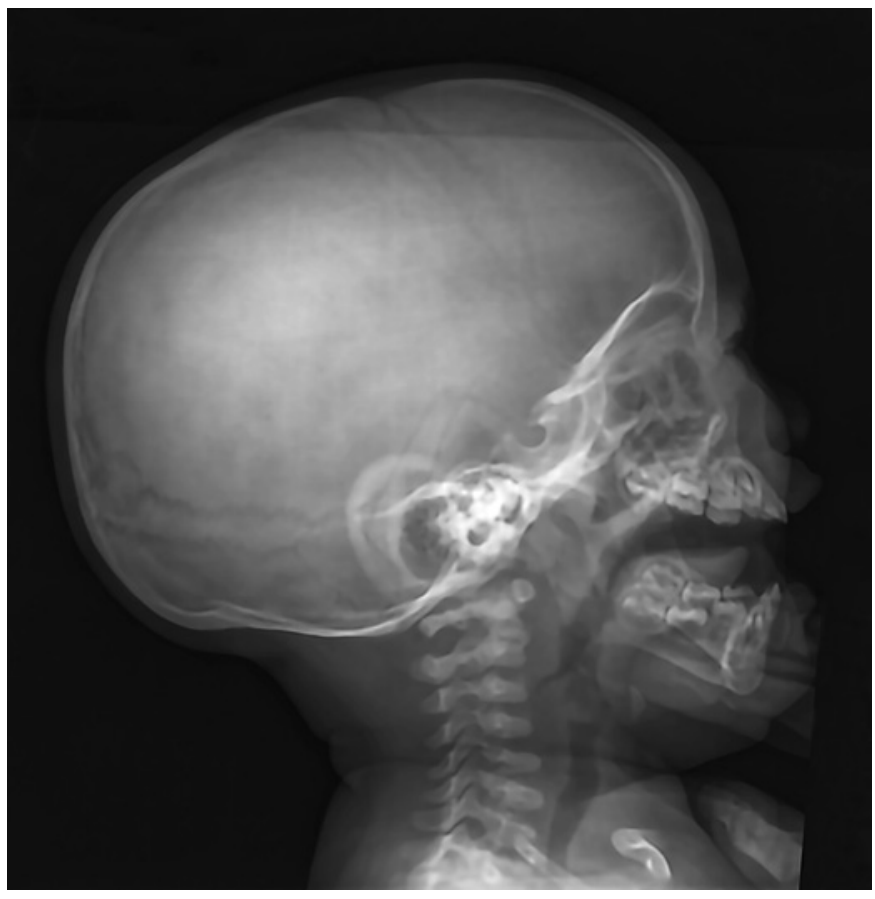

Fig. 1. Skull X-ray showing absent nasal bone.

early onset of bleeding was first described by McMillan and Roberts [3] in 1966 and has subsequently been termed vitamin K-dependent clotting factors deficiency (VKCFD) $[3,11]$. It is a very rare autosomal recessive disorder with a low incidence $(<30$ kindred worldwide reported) [2]. Biochemical and molecular studies identified two variants of this autosomal recessive disorder: VKCFD1, which is associated with point mutations in the $\gamma$-glutamyl carboxylase gene (GGCX), and VKCFD2, which results from point mutations in the vitamin $\mathrm{K} \mathrm{ep}$ - 
oxide reductase gene (VKOR) [10]. Bleeding ranges in severity from mild to severe [12].

In our case, the acquired causes of VKCFD were ruled out. Late-onset hemorrhagic disease of the newborn was unlikely as the patient received vitamin $\mathrm{K}$ at birth. There was no history of maternal drug ingestion, like warfarin or antibiotics. The patient was thriving well and there was no evidence of malabsorption.

With the suspicion of inherited VKCFD, whole-exome sequencing was performed. It detected a novel homozygous mutation (c.44_5T>A p.(?)) in the GGCX gene responsible for an autosomal recessive combined vitamin $\mathrm{K}$-dependent clotting factors deficiency type 1. Both parents were heterozygous.

Whole-exome sequencing detected another heterozygous (c.5191T>A, p.(Ser1731Thr)) mutation in the VWF gene responsible for autosomal dominant von Willebrand disease type 1 . However, we believe that this is unrelated to the patient's bleeding manifestations, especially since her von Willebrand factor level is normal and both parents carry the same variant and do not have any bleeding manifestation.

Surprisingly, whole-exome sequencing also detected a homozygous pathogenic variant (c.19G>A p.(Glu7Lys)) in the $\mathrm{HBB}$ gene responsible for hemoglobin $\mathrm{C}$ disease. $\mathrm{Hb}$ electrophoresis showed $\mathrm{Hb} \mathrm{C}$ of $88.7 \%$. Patients homozygous for $\mathrm{Hb} \mathrm{C}(\mathrm{Hb} \mathrm{CC}$ ) may have a mild degree of hemolytic anemia; however, our patient has stable hemoglobin throughout follow-up.

VKCFD-affected patients often show a varying pattern of nonhemostatic symptoms. Developmental and skeletal abnormalities resembling those seen in warfarin embryopathy are striking nonhemostatic features [2]. In our patient, the skeletal survey showed absent nasal bone, which might suggest a nonhemostatic manifestation of the disease.

In conclusion, hereditary combined VKCFD is a very rare congenital bleeding disorder. Vitamin K administration is the mainstay of therapy; nevertheless, response to treatment is extremely variable, so treatment should be tailored to individual needs. The overall prognosis is good with early diagnosis and appropriate management. We report this case to raise awareness among pediatricians to this very rare congenital bleeding disorder and its management.

To the best of our knowledge, there is no previously reported case of VKCFD combined with von Willebrand disease and hemoglobin $\mathrm{C}$ disease.

\section{Acknowledgement}

We thank the parents of the patient described for allowing us to share her details. We would also like to express our very great appreciation to Dr. M.K. for his valuable and constructive suggestions in writing this case report. His willingness to give his time so generously has been very much appreciated.

\section{Statement of Ethics}

The patient's parents gave their written informed consent to publish this case including the publication of images.

\section{Disclosure Statement}

The authors have no conflicts of interest to declare.

\section{Funding Sources}

None.

\section{Author Contributions}

S.A.A.: Wrote the manuscript.

M.A.R.: Supervised and revised the manuscript.

S.M.S.: Helped to supervise the manuscript.

M.A.A.: Helped in writing the discussion part of the manuscript.

\section{References}

1 Bhattacharyya J, Dutta P, Mishra P, Dixit A, Srinivas U, Kannan M. Congenital vitamin Kdependent coagulation factor deficiency: a case report. Blood Coagul Fibrinolysis. 2005; 16:525-7.

2 Napolitano M, Mariani G, Lapecorella M. Hereditary combined deficiency of the vitamin K-dependent clotting factors. Orphanet J Rare Dis. 2010 Jul;5(1):21.
3 McMillan CW, Roberts HR. Congenital combined deficiency of coagulation factors II, VII, IX and X. Report of a case [PubMed: 5936414]. N Engl J Med. 1966 Jun;274(23):1313-5.

4 Brenner B, Tavori S, Zivelin A, Keller CB, Suttie JW, Tatarsky I, et al. Hereditary deficiency of all vitamin K-dependent procoagulants and anticoagulants. Br J Haematol. 1990 Aug; 75(4):537-42.
5 Boneh A, Bar-Ziv J. Hereditary deficiency of vitamin K-dependent coagulation factors with skeletal abnormalities. Am J Med Genet. 1996 Oct;65(3):241-3.

6 Bhattacharyya J, Dutta P, Mishra P, Dixit A, Srinivas U, Kannan M, et al. Congenital vitamin K-dependent coagulation factor deficiency: a case report. Blood Coagul Fibrinolysis. 2005 Oct; 16(7):525-7. 
7 Pauli RM, Lian JB, Mosher DF, Suttie JW. Association of congenital deficiency of multiple vitamin $\mathrm{K}$-dependent coagulation factors and the phenotype of the warfarin embryopathy: clues to the mechanism of teratogenicity of coumarin derivatives. Am J Hum Genet. 1987 Oct;41(4):566-83.

8 Lapecorella M, Napolitano M, Bernardi F, Pinotti M, Sbrighi PS, Marchetti G, et al. Effective hemostasis during minor surgery in a case of hereditary combined deficiency of vitamin
K-dependent clotting factors. Clin Appl Thromb Hemost. 2010 Apr;16(2):221-3.

9 Vanakker OM, Martin L, Gheduzzi D, Leroy BP, Loeys BL, Guerci VI, et al. Pseudoxanthoma elasticum-like phenotype with cutis laxa and multiple coagulation factor deficiency represents a separate genetic entity. J Invest Dermatol. 2007 Mar;127(3):581-7.

10 Darghouth D, Hallgren KW, Shtofman RL, Mrad A, Gharbi Y, Maherzi A, et al. Compound heterozygosity of novel missense mu- tations in the gamma-glutamyl-carboxylase gene causes hereditary combined vitamin Kdependent coagulation factor deficiency. Blood. 2006 Sep;108(6):1925-31.

11 Weston BW, Monahan PE. Familial deficiency of vitamin K-dependent clotting factors. Haemophilia. 2008 Nov; 14(6):1209-13.

12 Abajas Y, Monahan PE. Congenital deficiency of vitamin K-dependent clotting factors disease overview. Rare Coagulation Disorders. 2014 